\title{
Using games at early stages in the secondary school Khaidarova A. ${ }^{1}$, Ramazanova A. ${ }^{2}$ (Republic of Kazakhstan) Использование игр на ранних стадиях в средней школе Хайдарова А. Б. ${ }^{1}$ Рамазанова А. Е. ${ }^{2}$ (Республика Казахстан)
}

\author{
${ }^{l}$ Хайдарова Аида Болатовна/ Khaidarova Aida - студентка английского отделения \\ ${ }^{2}$ Рамазанова Айгерим Ериковна/ Ramazanova Aigerim - преподаватель английского языка, \\ Педагогический колледж им. Ж. Мусина, г. Кокшетау, Республика Казахстан
}

\begin{abstract}
English lessons in secondary school. Because the games motivate students to study a foreign language and influences for the all sides of their development: the senses, the consciousness, the will and behavior.

Аннотация: в данной статье рассказывается о важности применения игровых технологий на уроках английского языка в средних классах. Так как игры мотивируют учеников к изучению иностранного языка и влияют на все стороны их развития: чувства, сознание, волю и поведение.
\end{abstract}

Keywords: foreign languages, games, teaching methods, secondary school. Ключевые слова: иностранные языки, игры, методы преподавания,средние классы.

Why do we use games at early stages in the secondary school? You think that children in secondary schools are adults, and they aren't interested in playing games.

Each age is good in its own way. At the same time, every age has its own characteristics, has its difficulties. There is no exception and adolescence. This is the longest period of transition, which is characterized by a number of physical changes.

This period includes the 5-8 grates. Pupils are 11-15 years old. They have already had some experience in learning a foreign language. If pupils have had good achievements in a language learning, they are usually interested in the subject, and work willingly both in class and at home. Their desire to learn depends fully on teachers' ability to involve each pupil in language activities during the lesson by asking questions which require thinking on the part of the learners, by presenting new facts that may be interesting to pupils, or playing the games with regards to the lesson that causes their interest and activity [1, 12].

At this age all brain functions are rapidly developing too, that is why the period is very good for studying and acquiring practical skills. But schools stop being the only place of getting knowledge. As it was told, at this age communication with friends comes to the first place, and teenager begins to be interested in many other things, besides study, volume of information received from other sources increases $[2,18]$.

That is why lessons should be very interesting and motivating. Only with this condition learning and school performance will be very successful. Boring lessons are the reason of discipline problems, missing classes and loss of interest and motivation. In this case, you can use games.

First of all, what is the game?

The game - a kind of unproductive activity, the motive of which is in its results and in the process. It is important in education, training and development of children as a means of psychological preparation for future situations. Game is an interesting and effective method of teaching in the educational activities of pupils and can be used at any stage of language learning.

General advantages of using games in the classroom include:

1. Games are a welcome break from the usual routine of the language class.

2. They are motivating and challenging.

3. Learning a language requires a great deal of effort. Games help students to make and sustain the effort of learning.

4. Games provide language practice in the various skills - speaking, writing, listening and reading.

5. They encourage students to interact and communicate.

6. They create a meaningful context for using language [3, 47].

Games have been shown to have advantages and effectiveness in learning vocabulary in various ways. First, games bring in relaxation and fun for students, thus help them learn and retain new words more easily. Second, games usually involve friendly competition and they keep learners be interested. These create the motivation for learners of English to get involved and participate actively in the learning activities. Third, vocabulary games bring real world context into the classroom, and enhance students' use of English in a flexible, communicative way. Therefore, the role of games in teaching and learning vocabulary cannot be denied. However, in order to achieve the most effective way from vocabulary games, it is essential that suitable games are chosen. Whenever a game is to be conducted, the number of students, proficiency level, cultural context, timing, learning topic, and the classroom settings are factors that should be taken into account $[4,95]$. 
When choosing games a teacher does not have to have a multitude of games, but there rather exists creativity at taking familiar or popular games and adapting it to the classroom to aim for maximum student involvement. Traditional games like hangman, Pictionary, charades, Chinese Whisper, Bingo, Snakes and Ladders, Battleships, «Who wants to be a millionaire?» can be modified and tailor-made for your learners and teaching content. Many games require modification in use when the students' needs are taken into consideration. It is also important to note that a game doesn't need to involve a lot of movement or excitement or cheering, but it does need to be intellectually challenging.

Teachers can use a variety of extra incentives to keep the energy in the classroom going during games with: group or team competition, using small prizes depending on age (stickers, stamps, reward points etc.) Games can definitely be used for all age groups, but some caution is needed when it is used for adult learners. Teachers have to ensure that their games belong to an appropriate age and not too easy or challenging for their students.

I think that one of the basic principles of foreign language teaching is the principle of comfort. The more favorable conditions in the classroom, the more intense are the assimilation of a foreign speech. Any stressful situation can destroy a child's desire to communicate with you. Using games to teach children to work in partnership and contribute to the creative potential.

The teacher should be aware of the benefits of using games as well as look after the right proportion of games with relation to other lesson activities in order not to overuse the games, which need to be implemented meaningfully to be able to serve their educational purposes.

Taking into consideration the amount of time students would like to dedicate to games in their language learning process, it would be very beneficial for teachers if also the students' and teachers' books consider the students' preferences and wishes. At this moment the educational language books present only small number of enjoyable and relaxing activities, if any, leaving all the initiatives to the teacher. If they care or have time to look for the suitable games themselves. Having suggestions of games for the particular part of curricula in the original course-book or the teacher's book would be of a great help to the teacher.

The last output to be highlighted hereby is the fact that the pupils may be very different and have different priorities. It is the teacher who needs to get to know his/her pupils. This helps not only to establish close and trusting relationship and learning environment but mainly to tailor the lesson style and activities to the concrete students' needs, which enables to run the lessons smoothly and with joy. This, in return, can result in both students' and teacher's contentment.

\section{References}

1. Волков Б. С. Психология подростка. - М.: 2009.

2. Philip Rice. Psychology of adolescence. - L.: 2010.

3. Kun Noemi. Games in Teaching English as a Foreign Language. Macmillan. 2010.

4. Cross David. A Practical Handbook of Language Teaching. Great Britain.: Duteous Limited, Trowbridge, Wiltshire.1991. 